\title{
Inquiry through Industrial Chemistry in Compulsory Secondary Education for the Achievement of the Development of the 21st Century Skills
}

\author{
María Diez-Ojeda ${ }^{1, *(\mathbb{D})}$, Miguel Ángel Queiruga-Dios ${ }^{1}$, Noelia Velasco-Pérez ${ }^{2}$, Emilia López-Iñesta ${ }^{3}(\mathbb{D}$ \\ and José Benito Vázquez-Dorrío ${ }^{4} \mathbb{D}$ \\ 1 Department of Specific Didactics, Universidad de Burgos, 09001 Burgos, Spain; maqueiruga@ubu.es \\ 2 Chemistry Department, Universidad de Burgos, 09001 Burgos, Spain; nvperez@ubu.es \\ 3 Department of Didactics of Mathematics, Universitat de València, 46022 València, Spain; emilia.lopez@uv.es \\ 4 Department of Applied Physics, Universidade de Vigo, 36310 Vigo, Spain; bvazquez@uvigo.es \\ * Correspondence: mdojeda@ubu.es
}

check for

updates

Citation: Diez-Ojeda, M.;

Queiruga-Dios, M.Á.; Velasco-Pérez,

N.; López-Iñesta, E.; Vázquez-Dorrío,

J.B. Inquiry through Industrial

Chemistry in Compulsory Secondary

Education for the Achievement of the Development of the 21st Century

Skills. Educ. Sci. 2021, 11, 475.

https://doi.org/10.3390/

educsci11090475

Academic Editor: Rüdiger Tiemann

Received: 8 July 2021

Accepted: 23 August 2021

Published: 29 August 2021

Publisher's Note: MDPI stays neutral with regard to jurisdictional claims in published maps and institutional affiliations.

Copyright: (c) 2021 by the authors. Licensee MDPI, Basel, Switzerland. This article is an open access article distributed under the terms and conditions of the Creative Commons Attribution (CC BY) license (https:// creativecommons.org/licenses/by/ $4.0 /)$.

\begin{abstract}
At a key moment when education systems are moving towards the development of 21stcentury skills at school, we propose to develop them with a series of enquiry activities connected to the real world on the subject of Chemistry in Compulsory Secondary Education. The four selected topics have practical aspects, as they are related to industrial chemistry, and are proposed in educational practice using the 5E model. The results obtained in a pilot test with 22 students show that the context created facilitates the development of 21st century competences. It is understood that this novel proposal can be successfully employed in other contexts.
\end{abstract}

Keywords: inquiry; IBL; industrial chemistry; secondary education; chemistry; 21st century skills

\section{Introduction}

Chemistry encompasses multiple branches of knowledge and crosses the barriers of the micro and macroscopic world, spreading throughout the universe. At the same time, Chemistry brings together the most archaic knowledge and techniques that have defined the development of humanity, science and technology. It is difficult to be aware of the main role of Chemistry in the world around us; we are surrounded by a complex and ordered system of chemical reactions, present in living organisms and in the rest of matter and phenomena occurring around us [1].

Chemistry was introduced as a high school curricular subject in 1866 in the Netherlands. Towards the end of the 19th century, the chemical industry began to boom in Europe and North America with the main role of products such as sulfuric acid, chlorine or sodium hydroxide. The Netherlands, with its traditional commercial character, identified the need to create an "expert" to analyze such industrial products, with the objective that secondary school students were instructed in this matter, making profits from the trade of these products, and ultimately creating a scientific knowledge that would favor the development of the country [2].

The reality, however, was far from the main objective of the Dutch government. The teaching of the new science was developed by graduate chemists, who focused their development on the scientific nature of the subject; they perceived the need to instruct students in a good general version of the scientific context. In this way, content adapted from the basic university texts was brought to school. For this reason, the curricular topics of the Chemistry subject are fundamentally an adaptation of the first university subject of General Chemistry, which is taught in most scientific careers. Thus, the Chemistry curriculum takes this main conceptual source, applying it to all courses, systematically developing the contents, deepening level by level [3]. The subject thus focused on learning: descriptive, working on systematic and ordered facts, based on already established knowledge; 
theoretical, presenting the theories, formulas, tables and symbols typical of scientific language, traditionally accepted by the scientific community, and with a small practical base, implementing simple laboratory techniques.

In Spain, for a long time, the dogmatic explanation of the contents of Chemistry in Compulsory Secondary Education has often been associated with an exclusive character of preparation for later university studies and with a deficient teacher training [4-6]. Some renovating proposals emphasize its educational nature, its relationship with the awakening of curiosity, the approach to the rigor and skills of science, as well as the interest in continuing to learn. Thus, at the beginning of the 20th century, Chemistry curricula encouraged practical work in the classroom and the organisation of visits and excursions. It was an attempt to make teaching more experimental, more participatory and more related to everyday life. However, this legislative proposal, except in specific cases, was limited in scope $[5,7]$. The last decades have also seen changes in Chemistry teaching in terms of content and teaching approaches. Whereas in the 1950s and 1960s the focus was on descriptive knowledge and its applications, in the 1970s and 1980s the conceptual aspects were emphasized, giving importance to chemical principles and the processes that lead to scientific knowledge. At present, Chemistry is still presented, in many cases, as a body of decontextualized knowledge and facts with no connection to the environment and leaving little room for the development of creativity $[8,9]$.

Research and discoveries in Chemistry have had a dizzying development since the middle of the 20th century. The great magnitude of the scientific-technological knowledge acquired supposes a problem for its introduction in the classroom. Some authors, like Wobbe de Vos et al. [2], have investigated the Chemistry curriculum, perceiving how new topics have been added in a sedimentary way, that is, building successive layers where some knowledge overlaps with others. This evolution of scientific knowledge in the field of Chemistry has not been accompanied, in general, by a change in the teaching of Chemistry. In this way, interest in this discipline (and in science in general) has been decreasing for years and is often accompanied by school dropouts or the abandonment of scientific disciplines $[10,11]$.

This study proposes the need to change the didactic strategies traditionally used for the teaching of Chemistry, returning the original objective of bringing the industry closer to the classroom, strengthening the relationship between Science, Technology and Society and seeking a competence development of students.

\section{Theoretical Framework}

Various studies carried out in recent years have highlighted the mistrust that many students have towards the discipline of Chemistry. The studies show that there are different factors that hinder the teaching-learning process of the discipline [12]: (a) High level of abstraction. The conceptual content is broad and abstract, and it can sometimes be difficult to establish the relationships between explanations and the phenomena studied; (b) Discrimination of chemical and physical laws. From a chemical point of view, matter has a discontinuous nature, consisting of small microscopic particles (atoms) in continuous interaction and movement, which define the macroscopic observable properties. Students, on the contrary, tend to make a static and continuous interpretation of material systems, conceiving them as they perceive them. This erroneous analysis may be due to confusion between two levels of interpretation: the study of the properties of the physical world at the macroscopic level and that of the microscopic composition of matter; (c) Theoretical framework overload. Chemistry curricula are oriented towards the principles and theories that define the structure and properties of matter, postponing the phenomenological aspects that constitute the central paradigm of this discipline: chemical change [13]; (d) Decontextualization with the social and natural environment. The conventional content of Chemistry focuses on the assimilation of laws, theories and models, the basis of scientific knowledge, without showing a good connection with the environment. In recent decades, different strategies have been developed to modify the teaching-learning process in Chemistry, 
based on working on the interaction between Science, Technology and Society for the construction of scientific knowledge [9,14].

Research and new innovation projects in the area of Chemistry Didactics aim to overcome these obstacles by implementing strategies to awaken interest in Chemistry. This work takes on a central role in view of the academic results of the subject, which is one of the subjects mainly involved in the problem of school failure. Student motivation is essential for meaningful learning to take place [15]. The learning process is closely linked to personal cognitive and affective aspects, although the first impulse to arouse interest and encourage the approach to the subject comes from outside, due to the essential action of the context in which the student develops; at this point, the teacher has a key task, to convey a favorable attitude towards learning, and passion for what is taught. Some alternatives for motivation Chemistry are: (a) Connection with everyday situations of interest-proposal of challenges and problems in which this science is involved; (b) Methodological approach to scientific research techniques; (c) Creation of interests and values that promote new attitudes focused on self-learning; (d) Positive view of scientific activity [16,17]. It is therefore necessary for teachers to generate educational activities that modify the limited artificial context in which science is taught $[17,18]$.

On the other hand, the last decades of the 20th century saw major changes in society and in the demands of work. These changes were facilitated by the great technological and social developments that were taking place. At the same time, they brought about changes in education to prepare students for the new challenges of the 21st century: to educate responsible, informed and committed people to improve society [19-25]. This requires education that goes beyond the cognitive mastery of disciplines and emphasizes competences [25]. Moreover, these skills also facilitate access to the world of work [26], and most skills are valuable in all careers, regardless of the workplace [27]. It is precisely the lack of these competences in workforce preparation that causes the shortage of professionals in scientific-technological areas, as warned by industry $[19,24,28-30]$. It is therefore a political and economic objective to prevent the skills gap in people intending to enter the labor market by promoting "skills and motivations that allow them to be flexible and adaptable to economic and organizational shocks" [28] (p. 104), without prejudice to achieve scientific literacy in society [31,32]. This must involve an imperative change in the approaches of educational institutions at the primary, secondary and post-secondary levels, which, to a large extent, are a product of the technological infrastructure and social circumstances [33].

When it comes to specifying the competencies that students must develop as citizens who must actively participate in society and integrate into the world of work, there are different competency frameworks that define 21st century skills, such as: Partnership for 21st century skills [34], EnGauge [35], Assessment and Teaching of 21st Century Skills (ATCS) [36], National Educational Technology Standards (NETS/ISTE) [37] and the National Assessment of Educational Progress (NAEP) [38]. In a comparative study conducted by the University of Twente [39], it was observed that some of the competencies appeared in all frames: Collaboration, Communication, ICT literacy, Social and/or cultural skills; citizenship, and also others appeared in most of the competency frameworks: Creativity, Critical thinking, Problem solving, Developing quality products/Productivity. However, although there are relationships and equivalences between the different competence frameworks, the question arises as to what kind of competences a science and technology-oriented baccalaureate student should develop and, subsequently, how the subject of Chemistry can contribute to the development of these competences.

Among the studies that seek to relate 21st century skills to the competences needed to embark on a scientific-technological career and which, therefore, should be developed from secondary education, those carried out by Fisher [40] and Fisher et al. [41] stand out. In these studies, carried out on 135 articles, 20 key competencies were selected that could intervene in the development of the skills necessary for a person to study a scientifictechnological career according to the ABET criteria [42,43]. These are: Civic Responsibility, Creativity, Critical Thinking, Cross-Cultural Skills, Disciplinary Knowledge, Ethics, Global 
Awareness, Humanitarianism, Interpersonal Communication, Memory, Networking, Organizational Management, Problem Solving, Public Speaking, Self-Confidence, Self-Direction, Strategy, Teamwork, Time Management and Written Communication. A definition of these skills can be found in the Appendix A, which has been adapted to how the activities of Secondary school students can support their acquisition of knowledge and skills. The development of these competences can promote the development of technical and non-technical skills relevant in the context of science and technology education [40,41]. Considering that all accreditation systems (e.g., CDIO Proposal [44], IPMA [45], Tuning Project [46] and Tuning Latin America [47]) are in agreement [48], it can be thought that the competencies selected by Fisher [40] and Fisher et al. [41] would be aligned with the key competencies of the university curricula of many countries.

Once the competence structure of the learning that students must acquire has been defined, it is necessary to define the methodological approaches that lead to the acquisition of these competences [46]. These competencies will be achieved through the completion of appropriate learning activities [49], which is why they must be dynamic methodologies that involve students $[50,51]$.

Among the different didactic methodologies for the teaching-learning of Chemistry, inquiry-based teaching allows the student to approach scientific knowledge in the same way as scientist works [52]: "Inquiry is a set of interrelated processes in which scientists and students raise questions about the natural world and investigate a phenomenon" (p. 214), so that students acquire content knowledge (concepts and ideas), procedural knowledge (procedures and strategies used in all forms of scientific inquiry) and epistemic knowledge (the way in which ideas are justified and guaranteed in science) [53], (p. 7). Therefore, working in inquiry therefore allows students to develop scientific competencies while acquiring scientific knowledge.

Some aspects that are essential in inquiry learning are the following [54-56]:

- Students must recognize that science is more than memorization and knowledge of facts.

- Students should have the opportunity to develop new knowledge built from their prior knowledge and scientific ideas.

- Knowledge is influenced by the learner's social environment, so they should have the opportunity to learn from others.

- Students must take control of their own learning.

- The extent to which students are able to learn with deep understanding will influence how their knowledge transfers to real-life contexts.

Inquiry Based Learning (IBL) is therefore a constructivist model in which students learn from prior knowledge through interaction with phenomena and with peers [57,58]; that is, students acquire knowledge by reflecting on their experiences, communicating their thoughts, and learning to make connections between their own experience and the real world.

Inquiry-based learning approaches include the $5 \mathrm{E}$ model, which owes its name to the five stages, as depicted in Figure 1, which are developed continuously [54-56,58].

The five stages to which this model refers are: engagement, exploration, explanation, elaboration and evaluation.

- Engagement. This first phase involves learners in the learning task. The activities are aim to make connections with previous experiences and expose their misconceptions. The way of involving and focusing the instructional task can be through a question, the definition of a problem, the representation of a problematic situation or the presentation of an event.

- Exploration. The exploration activities are designed for students to have concrete experiences that allow them to formulate concepts, processes and skills that facilitate conceptual change [59-61]. It can be laboratory or educational software activities that can help generate new ideas, explore questions and possibilities, and design and lead to preliminary research. The teacher plays a facilitator and animator role at this stage. 
- Explanation. This phase focuses the students' attention on a particular aspect of their previous experiences and allows them to demonstrate their conceptual understanding, processing ability or behavior. It explains their understanding of the concept and allows teachers, in turn, to introduce a new concept, process, or skill, with an explanation that can guide them to a deeper understanding.

- Elaboration. During this phase learners discuss and carry out information and search tasks, presenting and defending their approach to the instructional task, resulting in a better definition of the task [54], (p. 10).

- Evaluation. This is the phase where learners use their acquired skills to assess their learning. In addition, they receive feedback on the appropriateness of their explanations. Informal assessment can take place at the beginning and during the development of the 5E cycle. Formal assessment can take place after the elaboration phase by assessing the results.

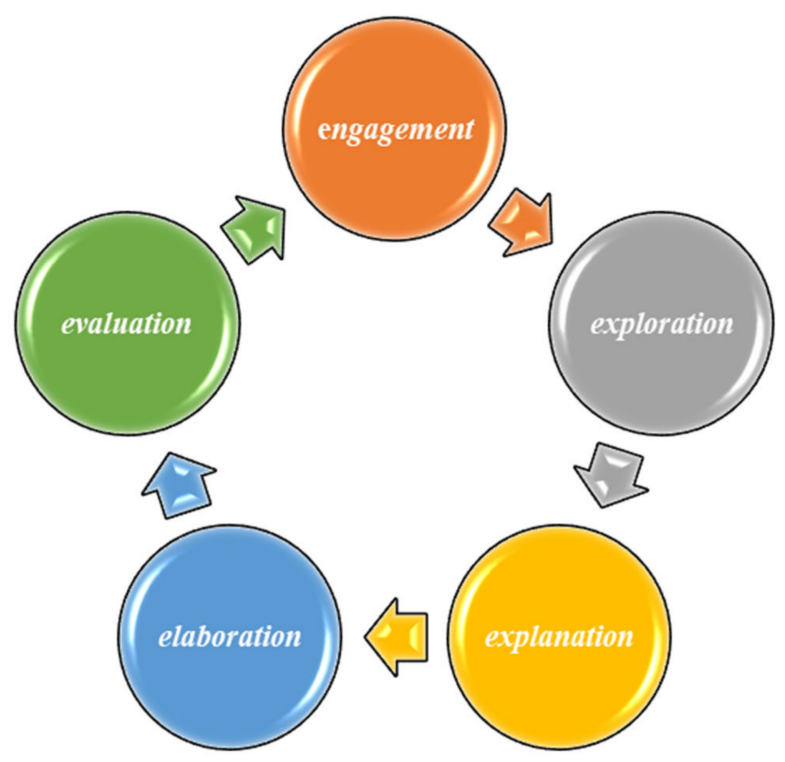

Figure 1. Representation of the stages of the 5E model of inquiry learning [54].

The inquiry methodology is a type of collaborative work, focused on the student seeking the solution to a problematic situation, enigma or mystery. It aims to encourage students' curiosity, introduce them to the process of scientific research so that they can reach the solution of the problem through reasonable and elaborated arguments, and seeks autonomous understanding of the topics and learning, encouraging the deepening and broadening of the contents [62].

With the aim of developing didactic strategies focused on making motivation effective in learning Chemistry, this article seeks to contextualize learning by working on the relationship between didactic content and the chemical industry in the students' environment. To do this, a set of inquiry activities were designed in which students analyze a commonly used compound based on an enigma. All the chemical compounds studied through the inquiry worksheets are related to the local chemical industry. Students must investigate their origin, the process of obtaining and transforming them, their applications and the relationship with the industry in their environment, as well as other proposed extension questions. This set of inquiry activities based on local industry was implemented in the classroom as a pilot test.

In the light of the above, the following research questions arise: can the implementation of inquiry activities based on the chemical industry support the development of 21st century skills, and can the analysis of students' outcomes allow us to determine which of the 21st century skills are being developed? 


\section{Research Objectives}

The proposed research objectives are as follows:

- To show how using inquiry-based activities in the teaching of Chemistry in Compulsory Secondary Education can help students develop 21st century skills.

- To analyze the results of student evaluation of a pilot test of the application of inquirybased activities in chemical engineering to determine what 21st century skills are being developed.

\section{Methodology}

\subsection{Participants}

The research sample is made up of 22 students (15-16 years old), 14 girls and 8 boys from Compulsory Secondary Education enrolled in an educational center in the downtown area of a city in northern Spain from families of medium-high socioeconomic level. Consent was obtained from the Directorate of the Center where the study was carried out. Likewise, all the participants and their families were informed of the objectives of this study and their consent was obtained. The specific assignment to the sample was carried out using convenience sampling.

\subsection{Instruments}

The instruments used for this study are the following:

- Chemical Engineering Inquiry Sheets "Rubber", "Graphene", "Gelatine" and "Plastic Containers", to work in the classroom according to the $5 \mathrm{E}$ methodology. These inquiry activities have been designed with the local chemical industry in mind (Bridgestone Hispania S.A., Grupo Antolín, Hispanagar and Torreplas S.L., respectively). In other words, each of the topics around which each inquiry is carried out is related to a specific local industry. Appendix B introduces, as an example, the inquiry form "Rubber".

- Assessment rubrics including systematic observation of students during class, inquiry report, teamwork and student oral presentation (Appendix C).

\subsection{Development of the Activity}

4.3.1. Regarding Objective 1: To Show How Using Inquiry-Based Activities in the Teaching of Chemistry in Compulsory Secondary Education Can Help Students Develop 21st Century Skills

The department's team of teachers designed what kind of student outcomes would be suitable for the development of 21st century skills.

These student outcomes were:

O1. Content: Quality of the content generated by the students as well as the rigor used to express the results of the inquiry.

O2. Answers to the questions: It has been assessed whether the students respond adequately to the questions posed by the teacher.

O3. Information Quality: The student obtains quality information when it is documented (using books, internet, etc.).

O4. Reflection and Structuring of Information: The student makes the appropriate reflections and structures the information related to the inquiry.

O5. Digital Resources: Use of different digital tools to prepare your report and present the results.

O6. Grammar and Spelling: The documents generated by the students are correctly written and do not contain spelling mistakes.

O7. Teamwork: Degree of involvement in cooperative work.

O8. Deadlines and Time: Adjustment to the timing of activities and delivery of results. O9. Exhibition: Quality of the exhibition, scientific rigor and means used.

In order to relate the results of the tasks developed during the project with the skills that are potentially being developed, 8 expert-teachers from Secondary and University were interviewed. 
4.3.2. Regarding Objective 2: To Analyze the Results of Student Evaluation of a Pilot Test of the Application of Inquiry-based Activities in Chemical Engineering to Determine What 21st Century Skills Are Being Developed

The inquiry activity was implemented by dividing the students into work groups with 4-5 students, assigning the cooperative roles of: direction, secretary, spokesperson and time manager. The role of the teacher in this activity focuses on guiding the entire inquiry process; teacher begins by presenting the project to the whole class and posing the starting mystery, then teacher encourages each group to work in their team, in which he or she reviews and supervises all the work.

As an example of the implementation process, the specific file entitled "Rubber" (Appendix B) is described. This activity focuses on the study of one of the most widely used polymers in the chemical industry. The inquiry process begins by presenting the activities to the students, and posing a starting mystery (engage), for which real rubber samples and tire sections are used. Subsequently, the students are guided through the phases of the inquiry process (explore, explain, elaborate). The students had to work in their workbook, being able to search for information (using computer equipment connected to the internet made available to them during class) and ask the teacher. Later, they had to deliver a report and create a presentation to show their results to the rest of the teams. The rubber and tire samples used have been obtained thanks to the collaboration with the company Bridgestone S. A. of the city of Burgos, whose industrial activity is closely linked to the content of the project.

The development of the inquiry activity is synthesized in the following stages:

Engagement: Students observe a sample of natural rubber and a cut section of the tire; wondering what differences he appreciates, and what process has taken place to produce that transformation.

Exploration: To investigate what is happening, the working groups inquire about rubber (chemical composition, properties, production, ... ), tires (raw materials and manufacturing process) and the role of these elements in the industry of their city, delving into the line of work of some of the companies dedicated to this sector.

Explanation: In the sheet (Appendix B) a series of questions are posed that guide the students. These questions seek to synthesize and focus the main ideas extracted in the exploration, and seek reflection and personal contribution of the solutions, duly reasoned and agreed in group.

Elaboration: A series of content is proposed to work on other aspects related to study materials, such as inquiring about other applications of rubber or recycling tires. This section seeks to awaken students' interest in science, and promote their autonomy.

Evaluation: This section includes the specific evaluation procedures of the project, so that students can adjust to them. Specifically, a slide presentation is requested, where all the constituent phases of the activity are collected, and the overall reflections of the group, self-evaluating their work and the usefulness of the activity.

\section{Results}

5.1. Regarding Objective 1: To Show How Using Inquiry-Based Activities in the Teaching of Chemistry in Compulsory Secondary Education Can Help Students Develop 21st Century Skills

The assessment items have focused on nine aspects (student outcomes) that are listed in Table 1 and are related to the competences whose development is being favored in the students with the definition of the core skills of Appendix A.

It can be seen that some of the skills of the 21st century are more favored with the outcomes designed in this approach of incorporation of the inquiry around industrial chemistry. Among the most favored are: Critical Thinking, Disciplinary Knowledge, Interpersonal Communication, Organizational Management, Self-Confidence and SelfDirection. Among the most disadvantaged are: Cross-Cultural Skills, Global Awareness and Humanitarianism. However, the designed activity favors the development of all the key skills of the 21st century according to the framework of Fisher [40] and Fisher et al. [41]. 
Table 1. Skills whose development is favored with each IBL outcome.

\begin{tabular}{|c|c|c|c|c|c|c|c|c|c|}
\hline Skill & O1 & $\mathrm{O} 2$ & $\mathrm{O} 3$ & $\mathrm{O} 4$ & O5 & O6 & O7 & O8 & O9 \\
\hline Civic Responsibility & & & & & & & $X$ & $X$ & \\
\hline Creativity & & $X$ & & & $X$ & & & & $x$ \\
\hline Critical Thinking & $x$ & $x$ & $x$ & $x$ & & & & & $X$ \\
\hline Cross-Cultural Skills & & & & & & & $x$ & & \\
\hline Disciplinary Knowledge & $X$ & $X$ & $x$ & $x$ & & & & & $X$ \\
\hline Ethics & $X$ & & & & & & $X$ & & \\
\hline Global Awareness & & & $X$ & & & & & & \\
\hline Humanitarianism & & & & & & & $x$ & & \\
\hline Interpersonal Communication & $X$ & $x$ & & $x$ & & & $x$ & & \\
\hline Memory & & & & $x$ & & & & & $x$ \\
\hline Networking & & & $X$ & & $X$ & & & & \\
\hline Organizational Management & & & $x$ & $x$ & $x$ & & $x$ & $x$ & $x$ \\
\hline Problem Solving & $x$ & $x$ & & & $x$ & & & & \\
\hline Public Speaking & & $x$ & & $x$ & & & & & $x$ \\
\hline Self-Confidence & & $X$ & & $\mathrm{X}$ & & & $X$ & & $X$ \\
\hline Self-Direction & $x$ & & $x$ & $x$ & $x$ & & & $x$ & $x$ \\
\hline Strategy & & & & & $x$ & & $X$ & & \\
\hline Teamwork & $x$ & & & & & & $x$ & & $X$ \\
\hline Time Management & & & & & & & & $x$ & $x$ \\
\hline Written Communication & $X$ & & & & & $x$ & & & $X$ \\
\hline
\end{tabular}

5.2. Regarding Objective 2: To Analyze the Results of Student Evaluation of a Pilot Test of the Application of Inquiry-Based Activities in Chemical Engineering to Determine What 21st Century Skills Are Being Developed

For the assessment of this activity, the investigation report, the group work carried out and the oral presentation were taken into account, in addition to the observations made in the classroom; using the corresponding rubrics (Appendix C). Table 2 shows the results of the scores corresponding to each student outcomes.

Table 2. Items and mean scores obtained by students according to gender.

\begin{tabular}{|c|c|c|c|c|c|c|c|c|}
\hline \multirow[t]{2}{*}{ Item } & \multicolumn{2}{|c|}{$\begin{array}{c}\text { Girls } \\
n=14\end{array}$} & \multicolumn{2}{|c|}{$\begin{array}{l}\text { Boys } \\
n=8\end{array}$} & \multicolumn{2}{|c|}{ Total } & \multirow[t]{2}{*}{$U$} & \multirow[t]{2}{*}{$p^{*}$} \\
\hline & $\mathbf{M}$ & SD & $\mathbf{M}$ & SD & $\mathbf{M}$ & SD & & \\
\hline O1. Content & 3.14 & 1.03 & 3.25 & 1.04 & 3.18 & 1.01 & 53 & 0.87 \\
\hline O2. Answers to the questions & 2.79 & 0.80 & 2.75 & 0.71 & 2.77 & 0.75 & 55.5 & 1 \\
\hline O3. Information Quality & 2.71 & 0.47 & 2.5 & 0.53 & 2.64 & 0.49 & 44 & 0.44 \\
\hline $\begin{array}{l}\text { O4. Reflection and Structuring } \\
\text { of Information }\end{array}$ & 2.14 & 0.95 & 1.75 & 0.89 & 2.00 & 0.93 & 43 & 0.40 \\
\hline O5. Digital Resources & 2.21 & 0.43 & 2.13 & 0.35 & 2.18 & 0.39 & 51 & 0.76 \\
\hline O6. Grammar and Spelling & 2.57 & 0.76 & 2.25 & 0.89 & 2.45 & 0.80 & 44 & 0.44 \\
\hline O7. Teamwork & 3.00 & 1.04 & 2.5 & 0.93 & 2.82 & 1.01 & 42 & 0.36 \\
\hline O8. Deadlines and Time & 2.50 & 1.09 & 2.13 & 0.99 & 2.36 & 1.05 & 44.5 & 0.45 \\
\hline O9. Exhibition & 2.86 & 0.77 & 2.63 & 0.92 & 2.77 & 0.81 & 45.5 & 0.50 \\
\hline
\end{tabular}

* $p<0.05$. Note. The maximum score is $4 . \mathrm{M}=$ Mean, SD = Standard Deviation, $\mathrm{U}=$ Mann-Whitney U.

In general, the evaluation results are positive and there are no significant differences between boys and girls (at a confidence level of $95 \%$ ). However, it can be noted that, for example, in the item O4. Reflection and Structuring of Information, a score very close to 2 is observed, with the girls slightly above 2 but the boys below. In the item O7. Team work, girls score higher (3) than boys (2.5). It can also be seen that the highest score is obtained in the item O1. Contents: both boys and girls score high. 


\section{Discussion}

This study suggests that the teaching of Chemistry in Secondary Education can contribute to the development of 21st century competencies. With the investigative approach used and with the student outcomes used, it has been seen that the development of some of the competencies is more favored: Critical Thinking, Disciplinary Knowledge, Interpersonal Communication, Organizational Management, Self-Confidence and Self-Direction. Thus, favor toward the development of Critical Thinking and Disciplinary Knowledge can be considered as something inherent to the implementation of inquiry activities in Chemistry classes [63,64]. However, favoring the development of other types of competences in the context of Chemistry, such as Interpersonal Communication, Organizational Management, Self-Confidence and Self-Direction, requires the design of educational environments that involves peer interaction [65]. However, the development of these skills is related to permanence in studies and lifelong learning $[15,66]$.

The development of other skills is not so evident: Cross-Cultural Skills, Global Awareness and Humanitarianism. However, it should be noted that these generic skills are strongly interrelated (to achieve systemic competence it is necessary to first develop instrumental and interpersonal skills, for example) and, depending on the different careers, some generic skills may be more important than others, depending on the context of the professional practice $[46,48,49,67]$, but in any case they are developed by linking to the acquisition of specific competences [46,50]. On the other hand, this competence development can be favored at school by incorporating, as has been seen, research activities. However, this development of competence will be more powerful if around the investigation activities we incorporate other actions that produce other new student outcomes. It should also be noted that the development of skills such as Cross-Cultural Skills or Humanitarianism will be more related to how the teacher implements the activity than to the activity itself. It is necessary for the teacher to take into account the principles of inclusion when doing the work groups and also in close contact with the students, favoring a climate of coexistence and guiding some debates in this regard. These skills would also be reinforced if scientific learning in the classroom were connected with citizen science projects [68] or service learning projects [69].

The relevance of the incorporation of inquiry activities to the teaching-learning process of Chemistry is unquestionable [52,54-56] and that this must be carried out in contexts that connect the contents with the students' environment $[12,14,16,18]$. This work shows a pilot test with a didactic material for the teaching of Chemistry in Compulsory Secondary Education according to the $5 \mathrm{E}$ inquiry methodology related to the context of chemical engineering in the industry in the immediate environment of the students involved. In view of the results found, it is convenient to reinforce in the students the reflection on chemical phenomena, which is precisely one of the focuses of interest of the investigative processes, since it is through reflection and response to the questions formulated by the teachers how inquiry can bring us closer to concepts necessary for the construction of science. However, all the results of the pilot test have been positive and the use of the described methodology produces an academic performance, on average, homogeneous of all the students, despite the fact that the gender variable is usually a significant predictor of the scientific performance of the student, with girls being the ones who usually obtain a lower average [70], although there is no difference between girls and boys in terms of ability [71].

\section{Conclusions}

The development of 21st century skills is necessary for students to integrate into society and access jobs in good conditions. The educational system should not provoke dichotomies: it is possible to achieve scientific literacy of students and it is possible at the same time to favor the development of 21st century skills.

From the teaching of Chemistry in Compulsory Secondary Education, the development of the skills of the 21st century can also be favored. To this end, it is necessary for the 
teaching staff to design activities that favor the development of these competences. The process of implementing activities in the classroom must be taken into account, but also, the creation of environments that develop the interest and self-concept of students improving their motivation, since this is a predictor of the development of inquiry skills [15]. These activities must be diverse and connected to the real world, allowing experiences that lead to the achievement of different student outcomes. In this way, the development of students scientific skills will be enhanced, improving their scientific literacy, which will produce critical citizens and, predictably, interest in scientific-technological careers will increase.

\section{Limitations and Future Lines of Research}

The limitations of the study include the size of the sample used (a single group of Secondary Education). However, the study is valid as a pilot test to make a sketch on how the implementation of inquiry activities in the Chemistry classroom should be done to favor the development of 21st century skills in students. At the same time, it would be necessary to implement instruments that would make it possible to assess students' prior competences, so that it would be possible to quantify a level in each competence. This would make it possible to design the activities and determine which products should be assessed in order to favor the development of those competences in which students show the greatest deficiencies, and also to measure the increase in competences. It should be noted that, as indicated, this article is research based on the results of a pilot test, so the psychometric properties and results of this study will be improved upon in subsequent iterations.

As future lines of research, it is proposed to analyze how to design the inquiry activities in an adaptive way so that it is possible to reinforce the development of one or other competences depending on the needs shown by the students. This will require a prior evaluation of the degree of development of skills in students.

Author Contributions: Conceptualization, J.B.V.-D., M.D.-O., N.V.-P. and M.Á.Q.-D.; methodology, M.D.-O.; formal analysis, J.B.V.-D. and M.Á.Q.-D.; investigation, N.V.-P., M.D.-O. and M.Á.Q.-D.; resources, N.V.-P.; data curation, M.D.-O.; writing—original draft preparation, M.Á.Q.-D., E.L.-I. and M.D.-O.; writing-review and editing, J.B.V.-D., M.D.-O., E.L.-I. and M.Á.Q.-D.; supervision, M.D.-O. and M.Á.Q.-D. All authors have read and agreed to the published version of the manuscript.

Funding: This research received no external funding.

Institutional Review Board Statement: The investigation was conducted with the permission of the parents and the Heads of the educa-tional center where it was carried out.

Informed Consent Statement: Informed consent was obtained from all subjects involved in the study.

Data Availability Statement: The data are not publicly available for confidentiality reasons. They are only available on request from the corresponding author.

Conflicts of Interest: The authors declare no conflict of interest. The funders had no role in the design of the study; in the collection, analyses, or interpretation of data; in the writing of the manuscript, or in the decision to publish the results.

\section{Appendix A. Core Skills Definition}

Civic Responsibility: Related with community organizing, editorial writing or lobbying.

Creativity: Encourages students to think "outside of the box" and develop innovative solutions to problems or challenges.

Critical Thinking: Capacity of the students to analyze complex problems and situations.

Cross-Cultural Skills: Requires students to interact with individuals-either peers or mentors-hailing from different cultural origins

Disciplinary Knowledge: Promotes students' development of skills within their engineering discipline.

Ethics: Presents students with professional or personal dilemmas that they are required to address. 
Global Awareness: Exposes students to international geopolitical or cultural issues.

Humanitarianism: Requires participants to address issues of equity, social justice, identity and engagement within their communities.

Interpersonal Communication: Requires students to communicate with their peers, mentors or-in some cases-mentees.

Memory: Requires memorization of large bodies of text or music.

Networking: Requires participating students to interact with individuals in their discipline or future professional field.

Organizational Management: Takes place when participating members are required to coordinate personnel and tasks to accomplish event preparation or other activities.

Problem Solving: Requires challenges presented to student members that they are required to overcome.

Public Speaking: Requires students to address large or small groups of individuals to communicate their or others' ideas.

Self-Confidence: Requires participants to try new things, participate in public speech or performance, and empower themselves through other activities.

Self-Direction: Requires student participants to independently self-motivate, complete projects and accomplish tasks.

Strategy: Defined as "political know-how" for the purposes of this study.

Teamwork: Requires students to work together to execute program tasks or reach ultimate organizational goals.

Time Management: When handling firm deadlines, such as with field operations or national/international competitions.

Written Communication: Requires students to write group materials or presentations such as business plans, etc.

\section{Appendix B. Chemical Industry in the Classroom. Organic Chemistry. Polymers \\ Rubber \\ INTRODUCTION}

Rubber is one of the elastic polymers, of natural or synthetic origin, most used in the chemical industry. The good properties and applications of this material mean that it has been used since ancient times, gradually evolving its methods of processing and use. At present, it stands out for being the main raw material in the manufacture of tires.

\section{APPROACH TO THE MYSTERY}

Observe the cut of a tire section provided by the teacher.

What materials do you distinguish with the naked eye in their composition?

Compare it with a sample of natural rubber, what differences are observed?

\section{EXPLORATION}

\section{What is happening?}

Look for information about the following contents:

1. Raw Materials for the manufacture of tires.

2. Industrial manufacturing process.

3. Factories in the city of Burgos dedicated to this work.

4. Focusing on natural rubber to investigate: its chemical composition, its properties and characteristics, and the natural process of obtaining.

\section{EXPLANATION}

\section{What causes this?}

Analyzing the above information, answer the following questions:

- What differences are observed between the rubber and the final rubber of the tires?

- What is the key chemical process that causes this transformation?

- How has this process evolved throughout history?

- What properties of rubber make it be used in the manufacture of these products? 
- What companies exist in your environment dedicated to this manufacture? Select one of them, investigate what products they manufacture. How do you assess the importance of these in your daily life?

\section{EXTENSION}

Once the process of making a common product such as tires has been investigated, we continue to deepen the use of these materials:

First, other applications for rubber will be investigated.

And secondly, the process of recycling and reuse of tires will be addressed.

EVALUATION

- The research work on rubber is carried out in groups.

- A final report is made, where the information collected in the work is presented, the answer to the questions raised and the final reflections specified below.

Final Reflections

- $\quad$ Rate team work.

- What have you learned from this little inquiry?

- After doing the work, how do you assess the importance of rubber in our daily lives? 


\section{Appendix C}

\begin{tabular}{|c|c|c|c|c|}
\hline \multicolumn{5}{|c|}{ Evaluation Rubric } \\
\hline & 4 & 3 & 2 & 1 \\
\hline O1. Content & $\begin{array}{l}\text { The report incorporates all the } \\
\text { indicated sections. }\end{array}$ & $\begin{array}{l}\text { The report incorporates between } 75-50 \% \\
\text { of the sections. }\end{array}$ & $\begin{array}{l}\text { The report incorporates between } \\
50-25 \% \text { of the sections. }\end{array}$ & $\begin{array}{c}\text { The report incorporates less than } 25 \% \text { of } \\
\text { the sections. }\end{array}$ \\
\hline $\begin{array}{l}\text { O2. Answers to } \\
\text { questions }\end{array}$ & $\begin{array}{l}\text { All questions asked are correctly } \\
\text { answered. }\end{array}$ & $\begin{array}{l}75 \% \text { of the questions are } \\
\text { correctly answered. }\end{array}$ & $\begin{array}{l}50 \% \text { of the questions are } \\
\text { correctly answered. }\end{array}$ & $\begin{array}{l}\text { Less than } 50 \% \text { of the questions are } \\
\text { correctly answered. }\end{array}$ \\
\hline $\begin{array}{l}\text { O3. Quality of the } \\
\text { information }\end{array}$ & $\begin{array}{l}\text { The information is original and is } \\
\text { presented elaborate. }\end{array}$ & The information is original, but it is brief. & $\begin{array}{l}\text { The information is original, but not } \\
\text { very elaborate. }\end{array}$ & $\begin{array}{l}\text { The information is original, but it is not } \\
\text { adapted to what is required. }\end{array}$ \\
\hline O4.1. Reflection & $\begin{array}{l}\text { The answers present a } \\
\text { deep reflection. }\end{array}$ & Responses show superficial reflection. & $\begin{array}{l}\text { The answers present a vague and } \\
\text { erroneous reflection. }\end{array}$ & $\begin{array}{l}\text { Only some answers contain a vague } \\
\text { and erroneous reflection. }\end{array}$ \\
\hline $\begin{array}{l}\text { O4.2. Information } \\
\text { Structuring }\end{array}$ & $\begin{array}{l}\text { The information structure } \\
\text { is excellent. }\end{array}$ & $\begin{array}{l}\text { The information structure is adequate, } \\
\text { but can be improved. }\end{array}$ & $\begin{array}{l}\text { The information structure has } \\
\text { important shortcomings. }\end{array}$ & $\begin{array}{l}\text { The information is displayed } \\
\text { in a disorderly. }\end{array}$ \\
\hline O5. Digital Resources & $\begin{array}{l}\text { The report is accompanied by a } \\
\text { diversity of digital resources (video, } \\
\text { image, web pages, etc.), some } \\
\text { prepared by the students. }\end{array}$ & $\begin{array}{l}\text { The report is accompanied by a variety of } \\
\text { resources (video, image, web pages, etc.). }\end{array}$ & $\begin{array}{c}\text { The report is accompanied by some } \\
\text { digital resources. }\end{array}$ & $\begin{array}{l}\text { The work does not contain } \\
\text { digital resources. }\end{array}$ \\
\hline $\begin{array}{l}\text { O6. Grammar and } \\
\text { spelling }\end{array}$ & $\begin{array}{l}\text { There are no grammatical or } \\
\text { spelling errors. }\end{array}$ & $\begin{array}{l}\text { There are hardly any grammatical or } \\
\text { spelling errors. }\end{array}$ & $\begin{array}{l}\text { There are quite a few grammatical and } \\
\text { spelling errors. }\end{array}$ & $\begin{array}{l}\text { There are many grammatical and } \\
\text { spelling errors. }\end{array}$ \\
\hline $\begin{array}{l}\text { O7.1. Cooperative } \\
\text { work }\end{array}$ & $\begin{array}{l}\text { The group has been organized } \\
\text { according to roles and develops the } \\
\text { activity adequately. }\end{array}$ & $\begin{array}{l}\text { The group has been organized according } \\
\text { to the roles and develops the activity } \\
\text { properly. On occasion is distracted. }\end{array}$ & $\begin{array}{l}\text { The group has not been organized } \\
\text { according to the roles, although they } \\
\text { carry out the activity. Some people in } \\
\text { the group just watch. }\end{array}$ & $\begin{array}{c}\text { The group has not been organized } \\
\text { according to the roles, and some people } \\
\text { in the group just watch. Sometimes they } \\
\text { talk about things unrelated to } \\
\text { the activity. }\end{array}$ \\
\hline O7.2. Team work & $\begin{array}{l}\text { Group work is shown (all team } \\
\text { members answer questions from } \\
\text { any part of the work). }\end{array}$ & $\begin{array}{l}\text { Group work is not shown (each member } \\
\text { answers questions about a part of the } \\
\text { work), although the parts are related. }\end{array}$ & It is about individual work put together. & No type of group work is observed. \\
\hline $\begin{array}{l}\text { O8. Deadlines and } \\
\text { Time }\end{array}$ & $\begin{array}{l}\text { The completed work is presented } \\
\text { within the agreed deadline. }\end{array}$ & By the deadline, the work is incomplete. & $\begin{array}{l}\text { Within the set deadline, the work } \\
\text { delivered is incomplete } \\
\text { and unstructured. }\end{array}$ & Work is not submitted by the deadline. \\
\hline
\end{tabular}




\section{4}

The presentation is attractive The presentation is appropriate, the

O9.1. Presentation

style

(videos, examples) and the correct

and clear expression to explain

the content.

O9.2. Information

processing

There is conceptual rigor in the

treatment of information. presentation is entertaining at times, the report is not read. and gestures, eye contact.

The exposition is generally correct, albeit unclear, and generally,

appropriate gestures, eye contact, or tone of voice are not used.

In general, the information is well treated and it seems that the students have understood a large part of the assigned topic.

The information is not treated, in general with conceptual rigor and the reasoning is not timely.

In addition to the presentation, they have prepared another element for their exhibition (poster or video).

They do not use an appropriate

presentation style, the expression is not correct or clear, and they continually read from the slides.

The students do not treat the information with conceptual rigor and do not seem to have understood the assigned topic.

\section{O9.3. Elements used \\ Used different elements for the} presentation (poster, video, slides) in the exhibition use paper.
Used a proper slide show.

Used a very simple presentation or just 


\section{References}

1. Pinto, G. Didáctica de la Química y Vida Cotidiana [Didactics of Chemistry and Everyday Life]; ETSII-UPM: Madrid, Spain, 2003; pp. 9-12.

2. De Vos, W.; Astrid, B.; Albert, P. Chemestry Curricula For General Education: Analysis and Elements of a Design. In Chemical Education: Towards Research—Bases Practice; Gilbert, J.K., De Jong, O., Justi, R., Treagust, D.F., Van Driel, J.H., Eds.; Kluwer Academic Publisher: Dordrecht, The Netherlands, 2002; pp. 101-124.

3. Galagovsky, L. La enseñanza de la Química pre-universitaria: ¿Qué enseñar, cómo, cuánto, para quiénes? [The teaching of pre-university Chemistry: What to teach, how, how much, for whom?). Quimica Viva 2005, 4, 8-22.

4. Giner de los Ríos, F. Grados naturales de educación [Natural degrees of education]. Bol. Inst. Libre Enseñ. 1897, 21, 1-4.

5. López-Martínez, J.D. La Enseñanza de la Física y de la Química en la Educación Secundaria en el Primer Tercio del Siglo XX en España [The Teaching of Physics and Chemistry in Secondary Education in the First Third of the 20th Century in Spain]. Ph.D. Thesis, Universidad de Murcia, Murcia, Spain, 1999.

6. Viñao, A. La crisis del bachillerato tradicional y la génesis de la educación secundaria. ¿Necesidad o virtud? [The crisis of the traditional high school and the genesis of secondary education. Necessity or virtue?]. Jorn. Educ. Secund. 1996, 1996, 137-155.

7. Martín-Sánchez, M.; Pinto, G.; Martín-Sánchez, M.T. Una aproximación a la historia de la enseñanza de la Química en España en niveles no universitarios [An approach to the history of Chemistry teaching in Spain at non-university levels]. An. Quim. 2016, $112,231-241$.

8. Caamaño, A. La enseñanza de la química en el inicio del nuevo siglo. Una perspectiva desde España [The teaching of chemistry at the beginning of the new century. A perspective from Spain]. Educ. Quím. 2001, 12, 7-17.

9. Caamaño, A. Retos del currículum de química en la educación secundaria. La selección y contextualización de los contenidos de química en los currículos de Inglaterra, Portugal, Francia y España [Challenges of the chemistry curriculum in secondary education. The selection and contextualization of chemistry content in the curricula of England, Portugal, France and Spain]. Educ. Quim. 2006, 17, 195-208.

10. Boiko, A.; Nistor, A.; Kudenko, I.; Gras-Velazquez, A. The Attractiveness of Science, Technology, Engineering and Mathematics Subjects. Results from Five Countries; European Schoolnet: Brussels, Belgium, 2019.

11. Henriksen, E.K. Introduction: Participation in science, technology, engineering and mathematics (STEM) education: Presenting the challenge and introducing Project IRIS. In Understanding Student Participation and Choice in Science and Technology Education; Springer: Dordrecht, The Netherlands, 2015; pp. 1-14.

12. Pozo, J.; Gómez, M. La enseñanza de la Química [Teaching Chemistry]. In Aprender y Enseñar en Ciencia; Morata: Madrid, Spain, 2000; pp. 150-152.

13. Hernández, G.; Montgaut, P. ¿Qué ocurrió con la magia de la Química? [What happened to the magic of Chemistry?]. ANUIEX 1991, 20, 1-4.

14. Furió-Más, C. La motivación de los estudiantes de la Química. Una cuestión controvertida [The motivation of students of Chemistry. A controversial issue]. Educ. Quím. 2006, 17, 222-227. [CrossRef]

15. Nehring, A.; Nowak, K.H.; zu Belzen, A.U.; Tiemann, R. Predicting students' skills in the context of scientific inquiry with cognitive, motivational, and sociodemographic variables. Int. J. Sci. Educ. 2015, 37, 1343-1363. [CrossRef]

16. Fernández-López, J.; Moreno, J. La química en el aula: Entre la ciencia y la magia [Chemistry in the classroom: Between science and magic]. In Proceedings of the I Jornadas Sobre Nuevas Tendencias en la Enseñanza de las ciencias y las Ingenierías, Murcia, Spain, 16-18 October 2008; Available online: http:/ / hdl.handle.net/10317/1088 (accessed on 19 June 2021).

17. Fischer, H.E.; Klemm, K.; Leutner, D.; Sumfleth, E.; Tiemann, R.; Wirth, J. Framework for empirical research on science teaching and learning. J. Sci. Teach. Educ. 2005, 16, 309-349. [CrossRef]

18. Garmendia, M.; Guisasola, J. Alfabetización científica en contextos escolares: El proyecto Zientzia Live! [Scientific Literacy in School Contexts: The Zientzia Live!]. Rev. Eureka Sobre Enseñan. Divulg. Cienc. 2015, 12, 294-310.

19. Bybee, R.W. The Case for Stem Education: Challenges and Opportunities; NSTA Press: Arlington, VA, USA, 2013.

20. Herro, D.; Quigley, C.; Andrews, J.; Delacruz, G. Co-Measure: Developing an assessment for student collaboration in STEAM activities. Int. J. STEM Educ. 2017, 4, 1-12. [CrossRef]

21. Kelley, T.R.; Knowles, J.G. A conceptual framework for integrated STEM education. Int. J. STEM Educ. 2016, 3, 1-11. [CrossRef]

22. National Research Council (NRC); Committee on Learning Science in Informal Environments; Board on Science Education, Center for Education; Division of Behavioral and Social Sciences and Education. Learning Science in Informal Environments: People, Places, and Pursuits; Bell, P., Lewenstein, B., Shouse, A.W., Feder, M.A., Eds.; The National Academies Press: Washington, DC, USA, 2009. [CrossRef]

23. National Research Council (NRC); Committee on Defining Deeper Learning and 21st Century Skills; Board on Testing and Assessment and Board on Science Education; Division of Behavioral and Social Sciences and Education. Education for Life and Work: Developing Transferable Knowledge and Skills in the 21st Century, Pellegrino, J.W., Hilton, M.L., Eds.; The National Academies Press: Washington, DC, USA, 2012.

24. National Research Council (NRC). STEM Integration in K-12 Education: Status, Prospects, and an Agenda for Research; The National Academies Press: Washington, DC, USA, 2014. [CrossRef] 
25. UNESCO. World Declaration on Higher Education for the Twenty-first Century. In Proceedings of the UNESCO World Conference on Higher Education, Paris, France, 5-9 October 1998; Available online: https://unesdoc.unesco.org/ark:/48223/pf0000141952 (accessed on 19 June 2021).

26. Díaz-Camacho, C.R.; López-Regalado, O. Estrategia de enseñanza-aprendizaje basado en problemas (ABP) para el logro de la competencia del proyecto tuning: Desarrollo de un planteamiento estratégico. Táctico y operativo en los estudiantes universitarios [Problem-based teaching-learning strategy (PBL) to achieve the competence of the tuning project: Development of a strategic approach. Tactical and operational in college students]. Didáct. Innov. Multimed. 2016; 34, 1-10.

27. National Research Council (NRC). Assessing 21st Century Skills: Summary of a Workshop; National Academies Press: Washington, DC, USA, 2011. [CrossRef]

28. Centre for the Development of Vocational Training (Cedefop). Skill Shortages and Gaps in European Enterprises: Striking a Balance between Vocational Education and Training and the Labour Market; Cedefop Reference Series No. 102; Publications Office of the European Union: Luxembourg, 2015. [CrossRef]

29. Eurofound. Third European Company Survey (ECS). 2013. Available online: https://www.eurofound.europa.eu/surveys/datavisualisation/3rd-european-company-survey-ecs (accessed on 13 June 2021).

30. Rodríguez-Pose, A.; Wilkie, C. Innovation and competitiveness in the periphery of Europe. In Handbook of Regions and Competitiveness: Contemporary Theories and Perspectives on Economic Development; Huggins, R., Thompson, P., Eds.; Edward Elgar Publishing: Cheltenham, UK, 2017; pp. 351-373.

31. Education Council (EC). Report from the Education Council to the European Council: "The Concrete Future Objectives of Education and Training Systems"; European Council: Brussels, Belgium, 2001; Available online: https://goo.gl/b7AbMP (accessed on 8 August 2021).

32. Council of the European Union (CE). Council Recommendation of 22 May 2018 on Key Competences for LifeLong Learning (Text with EEA relevance) (2018/C 189/01). Off. J. Eur. Union 2018, 61, C189/1-C189/13.

33. Davies, A.; Fidler, D.; Gorbis, M. Future Work Skills 2020; University of Phoenix Research Institute: Phoenix, AZ, USA, 2011; Available online: http:/ / www.iftf.org/futureworkskills / (accessed on 15 June 2021).

34. Partnership for 21st Century Skills (P21). A Framework for 21st Century Learning; P21: Tucson, AZ, USA, 2009; Available online: www.21stcenturyskills.org (accessed on 19 June 2021).

35. Lemke, C. enGauge 21st Century Skills: Digital Literacies for a Digital Age; North Central Regional Educational Laboratory (NCREL): Naperville, IL, USA, 2002. Available online: https: / / files.eric.ed.gov/fulltext/ED463753.pdf (accessed on 19 June 2021).

36. Care, E.; Griffin, P.; McGaw, B. Assessment and Teaching of 21st Century Skills; Springer: Dordrecht, The Netherlands, 2012. [CrossRef]

37. International Society for Technology in Education (ISTE). National Education Standards; ISTE: Washington, DC, USA, 2000; Available online: www.iste.org/standards/nets-for-teachers.aspx (accessed on 19 June 2021).

38. Neidorf, T.S.; Binkley, M.; Stephens, M. Comparing Science Content in the National Assessment of Educational Progress (NAEP) 2000 and Trends in International Mathematics and Science Study (TIMSS) 2003 Assessments; Technical Report; NCES 2006-026; National Center for Education Statistics: Washington, DC, USA, 2006. Available online: https://files.eric.ed.gov/fulltext/ED491191.pdf (accessed on 11 August 2021).

39. Voogt, J.; Roblin, N.P. 21st Century Skills; Discussienota; Kennisnet: Zoetermeer, The Netherlands, 2010; Volume 23, p. 2000. Available online: http:/ / www.billielee.co.nz/wp-content/uploads/2015/04/White-Paper-21st-CS-Reading-week-2.pdf (accessed on 19 June 2021).

40. Fisher, D.R. Educating Engineers for the 21st Century: A Framework for Skill Development through Co-Curricular and Extracurricular Involvement. Ph.D. Thesis, Massachusetts Institute of Technology, Cambridge, MA, USA, 2013.

41. Fisher, D.R.; Bagiati, A.; Sarma, S. Developing professional skills in undergraduate engineering students through cocurricular involvement. J. Stud. Aff. Res. Pract. 2017, 54, 286-302.

42. Accreditation Board for Engineering and Technology (ABET). 2010-2011 Criteria for Accrediting Engineering Programs. Engineering Accreditation Commission. Effective for Evaluations during the 2010-2011 Accreditation Cycle. 2009. Available online: http:/ / www.abet.org (accessed on 19 June 2021).

43. ABET. Criteria for Accrediting Engineering Programs; ABET: Baltimore, MD, USA, 2012.

44. Crawley, E.F.; The CDIO Syllabus. A Statement of Goals for Undergraduate Engineering Education. 2001. Available online: http:/ / www.cdio.org (accessed on 19 June 2021).

45. International Project Management Association (IPMA). ICB-IPMA Competence Baseline Version 3.0; International Project Management Association: Nijkerk, The Netherlands, 2006.

46. González, J.; Wagenaar, R. (Eds.) Tuning Educational Structures in Europe; University of Deusto: Bilbao, Spain, 2003.

47. Tuning Latin America. Proyecto Tuning. 2011-2013 Innovación Educativa y Social. 2013. Available online: http://www.tuningal. org/ (accessed on 19 June 2021).

48. Queiruga-Dios, M.Á.; López-Iñesta, E.; Diez-Ojeda, M.; Sáiz-Manzanares, M.C.; Vázquez Dorrío, J.B. Developing Engineering Skills in Secondary Students Through STEM Project Based Learning. In Proceedings of the 11th International Conference on European Transnational Educational (ICEUTE 2020), Burgos, Spain, 16-18 September 2020; Herrero, Á., Cambra, C., Urda, D., Sedano, J., Quintián, H., Corchado, E., Eds.; Advances in Intelligent Systems and Computing. Springer: Cham, Switzerland, 2021; Volume 1266. [CrossRef] 
49. Montero-Curiel, M. El proceso de Bolonia y las nuevas competencias [The Bologna process and the new competences]. Tejuelo 2010, 9, 19-37.

50. Bybee, R.W. The BSCS 5E Instructional Model and 21st Century Skills; BSCS: Colorado Springs, CO, USA, 2009.

51. Fernández, T.E.; Aubin, V.I.; Guatelli, R.; Bellani, M.; Blautzik, L. Influencia de la educación inversa en el aprendizaje y adquisición de competencias transversales [Influence of reverse education on learning and acquisition of transversal skills]. In Proceedings of the XIX Workshop de Investigadores en Ciencias de la Computación (WICC 2017), Buenos Aires, Argentina, $27-28$ April 2017.

52. National Research Council (NRC); National Committee for Science Education Standards and Assessment. National Science Education Standards; The National Academy Press: Washington, DC, USA, 1996. [CrossRef]

53. OECD. PISA 2015. Draft Science Framework. 2013. Available online: http://www.oecd.org/pisa/pisaproducts/DraftPISA201 5ScienceFramework.pdf (accessed on 11 August 2021).

54. Bybee, R.W.; Taylor, J.A.; Gardner, A.; Van Scotter, P.; Powell, J.C.; Westbrook, A.; Landes, N. The BSCS 5E Instructional Model: Origins and Effectiveness; BSCS: Colorado Springs, CO, USA, 2006; Available online: https://media.bscs.org/bscsmw/5es/bscs_ 5e_full_report.pdf (accessed on 19 June 2021).

55. Carpineti, M.; Childs, P.; Dittmar, J.; Eilks, I.; Fortus, D.; Giliberti, M.; Yayon, M. Teching the TEMI Way. How Using Mysteries Supports Sciences Learning; TEMI: Brussels, Belgium, 2015; Available online: http:/ / projecttemi.eu/wp-content/themes/temi/ pdf/Temi_teaching_guidebook.pdf (accessed on 10 June 2021).

56. Queiruga-Dios, M.Á.; Sáiz-Manzanares, M.; Montero-García, C. Análisis de Protocolos en Alumnos de Educación Secundaria Obligatoria [Analysis of Protocols in Students of Compulsory Secondary Education]. Ph.D. Thesis, University of Burgos, Burgos, Spain, 2016. Available online: https: / / riubu.ubu.es/handle/10259/5050 (accessed on 19 June 2021).

57. Queiruga-Dios, M.A. Indagación, trabajo cooperativo y método científico en la enseñanza-aprendizaje de la física en Secundaria Obligatorio. Propuesta y reflexión [Inquiry, cooperative work and scientific method in the teaching-learning of physics in Compulsory Secondary. Proposal and reflection]. In Instructional Strategies in Teacher Training; Gómez-Galán, J., López-Meneses, E., García, L.M., Eds.; UMET Press: San Juan, Puerto Rico, 2016; pp. 317-329.

58. Queiruga-Dios, M.A. Indagación en entornos virtuales [Inquiry in virtual environments]. In Estrategias Didácticas para la Enseñanza de la Física; Meneses, J., Fontana, M.J., Eds.; Servicio de Publicaciones e Imagen Institucional de la Universidad de Burgos: Burgos, Spain, 2018; pp. 143-156.

59. Ben-David, A.; Zohar, A. Contribution of meta-strategic knowledge to scientific inquiry learning. Int. J. Sci. Educ. 2009, 31, 1657-1682. [CrossRef]

60. Gurt, C.F.; Tallada, A.M. Evaluación de habilidades de indagación [Inquiry Skills Assessment]. Enseñ. Cienc. Rev. Investg. Exp. Didác. 2017, 2017, 1241-1248.

61. Nowak, K.H.; Nehring, A.; Tiemann, R.; Upmeier zu Belzen, A. Assessing students' abilities in processes of scientific inquiry in biology using a paper-and-pencil test. J. Biol. Educ. 2013, 47, 182-188. [CrossRef]

62. Education Quality Agency. Talleres [Workshops]. 2017. Available online: http:/ / bit.ly / 2 GO44iK (accessed on 19 June 2021).

63. Sutrisno; Nanda, G.A.M.; Widarti, H.R. The effectiveness of inquiry based learning with OE3R strategy for conceptual understanding of molecular shape of high school students'. AIP Conf. Proc. 2020, 2215, 020025. [CrossRef]

64. Van Brederode, M.E.; Zoon, S.A.; Meeter, M. Examining the effect of lab instructions on students' critical thinking during a chemical inquiry practical. Chem. Educ. Res. Pract. 2020, 21, 1173-1182. [CrossRef]

65. Jabeen, F.; Afzal, M.T. Effect of simulated chemistry practicals on students' performance at secondary school level. J. Educ. Educ. Dev. 2020, 7, 119-139. [CrossRef]

66. Hall, J.A. Relationships of Self-Direction and Attitude toward Continuing Education in Community College Allied Health Programs. Ph.D. Dissertation, University of Tennessee, Knoxville, TN, USA, 2018. Available online: https://trace.tennessee.edu/ utk_graddiss/5280 (accessed on 19 June 2021).

67. González, J.; Wagenaar, R. (Eds.) Universities' Contribution to the Bologna Process; University of Deusto: Bilbao, Spain, 2008; Available online: https://www.unideusto.org/tuningeu/images/stories/Publications/ENGLISH_BROCHURE_FOR_WEBSITE. pdf (accessed on 19 June 2021).

68. Queiruga-Dios, M.Á.; López-Iñesta, E.; Diez-Ojeda, M.; Sáiz-Manzanares, M.C.; Vázquez-Dorrío, J.B. Citizen Science for Scientific Literacy and the Attainment of Sustainable Development Goals in Formal Education. Sustainability 2020, 12, 4283. [CrossRef]

69. Queiruga-Dios, M.; Santos, M.J.; Queiruga-Dios, M.A.; Acosta, P.M.; Queiruga-Dios, A. Assessment methods for service-learning projects in engineering in higher education: A systematic review. Front. Psychol. 2021, 2, 629231. [CrossRef] [PubMed]

70. Rodríguez-Mantilla, J.M.; Fernández-Díaz, M.J.; Olmeda, G.J. PISA 2015: Predictores del rendimiento en Ciencias en España [PISA 2015: Predictors of Science Performance in Spain]. Rev. Educ. 2018, 380, 75-102.

71. López-Iñesta, E.; Botella, C.; Rueda, S.; Forte, A.; Marzal, P. Towards Breaking the Gender Gap in Science, Technology, Engineering and Mathematics. IEEE Rev. Iberoam. Tecnol. Aprendiz. 2020, 15, 233-241. [CrossRef] 